\title{
Treating asthma means treating airway smooth muscle cells
}

\author{
S. Zuyderduyn*, M.B. Sukkar" ${ }^{\#}$, A. Fust ${ }^{\star}$, S. Dhaliwal ${ }^{\star}$ and J.K. Burgess ${ }^{+, \S}$
}

\begin{abstract}
Asthma is characterised by airway hyperresponsiveness, airway inflammation and airway remodelling. Airway smooth muscle cells are known to be the main effector cells of airway narrowing. In the present paper, studies will be discussed that have led to a novel view of the role of airway smooth muscle in the pathogenesis of asthma in which airway hyperresponsiveness, remodelling and inflammation are, at least in part, attributable to airway smooth muscle. Furthermore, how this new view may lead to a change in the phenotyping and treatment of patients with asthma will be discussed.
\end{abstract}

KEYWORDS: Airway hyperresponsiveness, airway inflammation, airway remodelling, airway smooth muscle, asthma therapy

\begin{abstract}
A sthma is defined in the Global Initiative for Asthma guidelines as a chronic inflammatory disorder characterised by reversible airways obstruction and airway hyperresponsiveness (AHR) [1]. Inflammation is thought to cause symptoms of asthma directly and indirectly by inducing contraction of airway smooth muscle (ASM), enhancing airway responsiveness to various stimuli and by inducing changes in structural components of the airway wall (including ASM cells) leading to airway remodelling, thereby implying that inflammation is the primary cause of airway dysfunction in asthma. However, studies in which patients with asthma were treated with antibodies against interleukin (IL)-5 [2] and immunoglobulin E [3, 4] have shown that, although inflammation is resolved and exacerbations are reduced, AHR does not improve. Thus, these data suggest that inflammation is not the primary cause of AHR in asthma.
\end{abstract}

\section{THE ROLE OF AIRWAY SMOOTH MUSCLE CELLS IN ASTHMA: A NOVEL VIEW}

ASM cells are thought to be the major effector cells of airway narrowing, although other factors, such as swelling of airway wall compartments and mucus plugging, may amplify the narrowing [5, 6]. AHR is defined as exaggerated airway narrowing due to nonspecific irritants or pharmacological agonists, which is reversible by bronchodilators that relax ASM, implying that ASM is the "bad guy". Many studies have focused on the nature of the change in ASM from asthmatics. ASM from asthmatics was thought to generate more force and, therefore, contract to a greater extent [7], or to have increased maximum shortening velocity and capacity [8]. Sensitisation of dog and human airways resulted in increased quantity and activity of myosin light chain kinase (MLCK) [7, 9], which phosphorylates myosin light chain, leading to contraction. MLCK mRNA expression was shown to be increased in asthmatic ASM compared with normal ASM [8]. In addition to MLCK, Rho kinase content and activity are increased upon allergen sensitisation in guinea pigs [10]. Rho kinase inhibits myosin light chain phosphatase, thereby altering the balance towards MLCK activity and contraction. However, as allergic sensitisation is only a model and does not fully reflect asthma, these abnormalities need to be confirmed in patients with asthma. An increase in ASM mass [11] and altered load on ASM by the surrounding tissue $[5,12,13]$ are other possible causes of increased airway narrowing in asthma. A recent review describes the dynamics of contractility and relaxation of ASM in asthma and summarises key literature discussing the role of ASM in airway narrowing [14].

In the present paper, the authors propose a novel view of the pathogenesis of asthma arising from previous studies showing that ASM cells are not only involved in airway narrowing, but also play a role in the remodelling and inflammation of the airways observed in asthma. In this view, the current authors propose that ASM cells contribute to AHR, remodelling and inflammation by virtue of their increased sensitivity to bronchoconstrictor

\section{AFFILIATIONS}

*Dept of Pulmonology, Leiden University Medical Center, Leiden, The Netherlands.

\#Airway Disease Section, Nationa Heart and Lung Institute, Imperial College London, London, UK.

"Dept of Physiology, University of Manitoba, Winnipeg, MB, Canada. ${ }^{+}$Respiratory Research Group,

Discipline of Pharmacology, Bosch Institute, University of Sydney, and ${ }^{\S}$ Woolcock Institute of Medical Research, Sydney, Australia.

\section{CORRESPONDENCE}

S. Zuyderduyn

Dept of Pulmonology

Building 1

C3-P

Leiden University Medical Center

P.0. Box 9600

$2300 \mathrm{RC}$

Leiden

The Netherlands

Fax: 31715266927

E-mail: s.zuyderduyn@lumc.nl

Received:

April 272007

Accepted after revision:

March 052008

\section{SUPPORT STATEMENT}

This manuscript was partly based on

the European Respiratory Society

research seminar "The bronchial

smooth muscle in airway

responsiveness" held in Gothenburg,

Sweden, in June 2004.

STATEMENT OF INTEREST

None declared.

European Respiratory Journal

Print ISSN 0903-1936

Online ISSN 1399-3003 
stimuli, increased proliferation and increased secretion of mediators (fig. 1). The present paper will discuss studies that support this view and will conclude with the concept that this novel view may lead to new strategies for phenotyping asthma and, consequently, the development of novel intervention strategies for asthma.

\section{ASM CELLS ARE A PART OF THE INFLAMMATORY PROCESS IN ASTHMA}

In the 1980s and 1990s, cultures of ASM cells isolated from lung tissue (trachea, bronchi) were established either by enzymatic digestion or the explant method [15, 16]. These cultures were used to study not only contractile responses but also mitogenic and synthetic responses, and this has led to the novel view that ASM cells are active players in inflammation.

\section{ASM phenotype}

Freshly isolated ASM cells are contractile, but upon culture in serum-rich conditions ASM cells modulate from a "contractile" phenotype to a "synthetic-proliferative" phenotype that lacks responsiveness to contractile agonists and has reduced expression of contractile proteins, such as smooth muscle myosin heavy chain (smMHC), smMLCK and smooth muscle $\alpha$-actin ( $\alpha$ SMA). However, these cells are highly proliferative in response to mitogens and produce extracellular matrix (ECM) proteins and cytokines [17]. Synthetic-proliferative cells can mature into contractile cells during lung development in dogs and this process can be mimicked in vitro by prolonged serum deprivation of canine ASM cells, leading to a "hypercontractile" phenotype with increased expression of $\alpha \mathrm{SMA}$, smMHC, SM22, desmin, calponin and $\mathrm{M}_{3}$ muscarinic receptors [18-21]. This modulation and maturation is known as phenotype switching (fig. 2). Whether this switching from contractile to synthetic-proliferative also takes place in vivo in humans

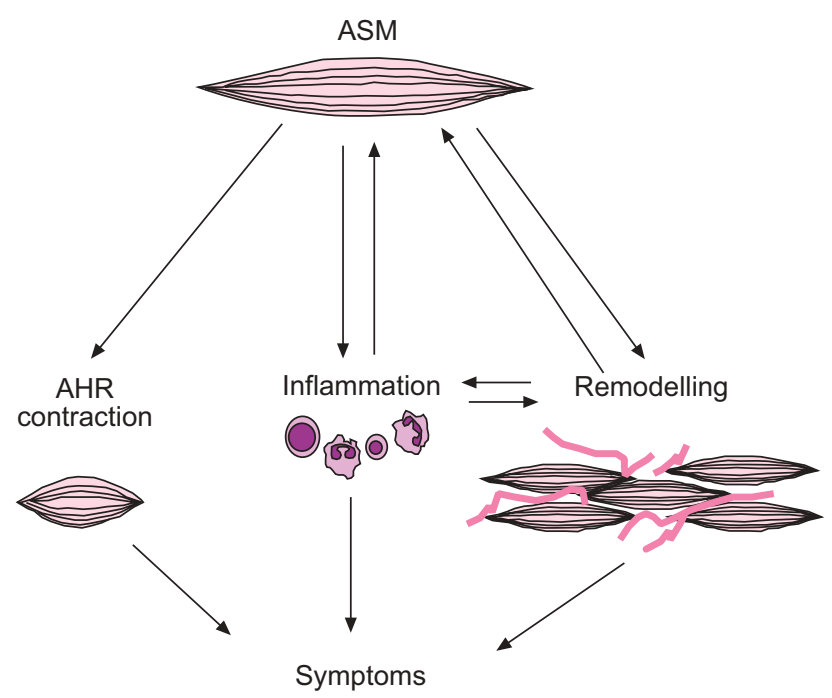

FIGURE 1. Schematic representation of the novel view of the role of airway smooth muscle (ASM) in asthma. ASM cells are involved in: airway hyperresponsiveness (AHR) by an exaggerated response to bronchoconstrictor stimuli; remodelling due to an increase in ASM mass and altered deposition of extracellular matrix; and inflammation by secreting cytokines, chemokines and growth factors. These three features will lead to symptoms of asthma. Likewise, remodelling and inflammation can also affect ASM function. remains to be established. Furthermore, both the existence of these two phenotypes of cells in vivo and whether the ratio of contractile versus synthetic-proliferative cells contributes to functional abnormalities need to be investigated. Historically, the contractile function of ASM cells was seen to be the most important function of these cells. However, studies with synthetic-proliferative cells have shown that ASM cells are a source of a wide variety of inflammatory mediators [22, 23].

\section{ASM secretory function}

A role for ASM cells as secretory cells involved in the recruitment of inflammatory cells is further highlighted by studies showing intra-ASM inflammation. AMMIT et al. [24] have shown that more mast cells are present in the smooth muscle of human sensitised bronchi compared with nonsensitised bronchi. The airways of patients with asthma and eosinophilic bronchitis are both infiltrated by eosinophils, but the airways of patients with eosinophilic bronchitis are not hyperresponsive to bronchoconstrictor stimuli. BRIGHTLING et al. [25] compared inflammation in the airways of these two patient groups and reported that the only difference was that the ASM layer from asthmatics was infiltrated by mast cells. In the asthmatic patients, a correlation was found between number of mast cells and PC20 (provocative concentration of methacholine that results in a $20 \%$ reduction in forced expiratory volume in one second (FEV1); a measure of AHR). Higher numbers of mast cells were associated with a lower PC20, which suggests that the mast cells may influence AHR in asthma. The correlation between intra-ASM mast cell numbers and AHR in asthmatics suggests that mast cells in the ASM bundles are responsible for the enhanced airway narrowing seen in asthmatics. With the discovery of intra-ASM inflammation, the altered secretory pattern of ASM from asthmatics and the putative interactions between mast cells and ASM cells have become the focus of many studies. It is thought that the ASM is responsible for the recruitment of the mast cells by secretion of mast-cell chemotaxins, including CCL11 [26], CXCL10 [27] and CX3CL1 [28]. Besides producing inducing factors, the lack of an inhibitory factor may also explain the increase in mast cell numbers in the ASM layer [29].

The interactions between mast cells and ASM cells are also being scrutinised. Cell-cell contact between these cells may be important for a functional interaction [30]. Mast cells adhere to ASM cells in part via a molecule known as tumour suppressor in lung cancer-1 [31]. Upon adhesion, the mast cells may release mediators including histamine, prostaglandin $\mathrm{D}_{2}$ and leukotriene $(\mathrm{LT}) \mathrm{C}_{4}$, which can induce contraction of ASM. Mast cell tryptase is also an important activator of ASM; it can induce cytokine release [32], induce proliferation of ASM cells [32-34] and potentiate the contractile response to histamine [35].

In summary, the secretory function of ASM cells may be very important in the recruitment of mast cells into the ASM bundles, and could lead to mast cell activation and subsequent alterations in ASM contractility and remodelling.

\section{ASM cell surface molecules and immunomodulatory function}

In addition to their secretory function, ASM cells also express many cell surface molecules, indicating that they may directly interact with immune cells or may have inherent immune 
Cultured ASM cells

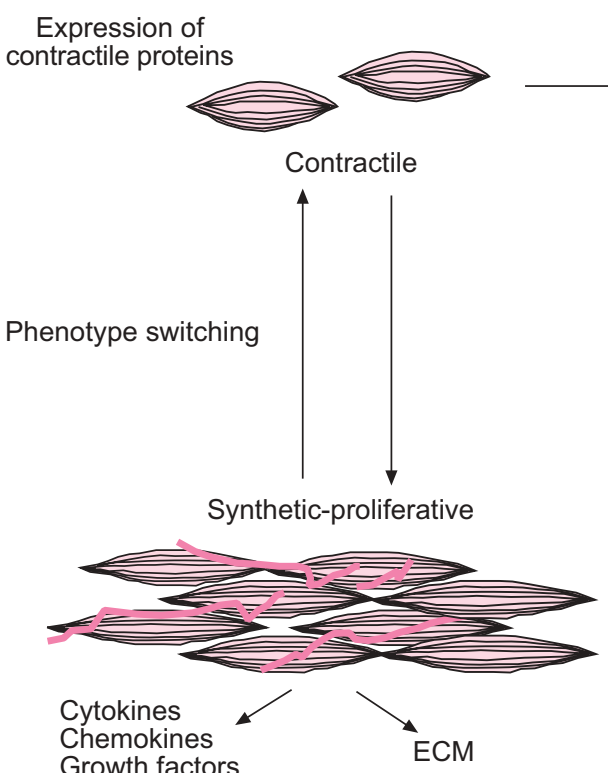

Asthmatic ASM cells

Hypercontractile

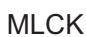

$\mathrm{c} / \mathrm{EBP} \alpha ?$

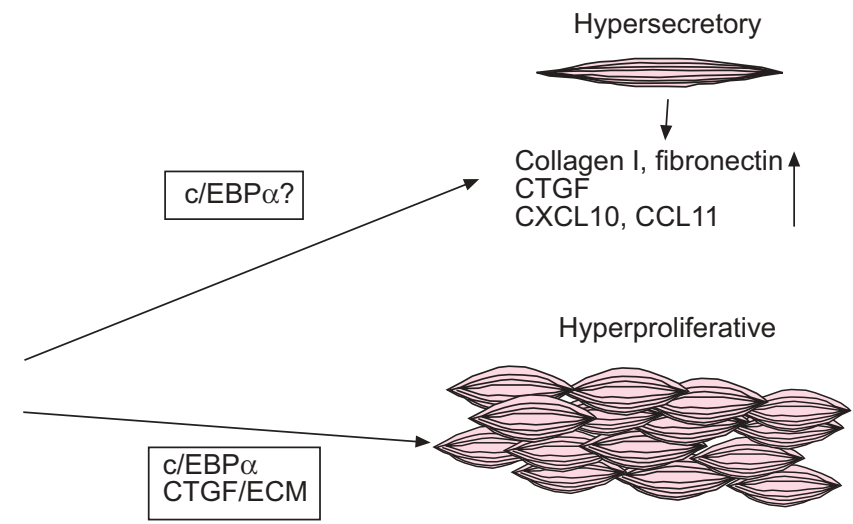

FIGURE 2. Phenotype switching in cultured airway smooth muscle (ASM) cells. ASM cells cultured from lung tissue can modulate from a "contractile" to a "syntheticproliferative" phenotype, which shows reduced expression of contractile proteins and increased proliferation and synthetic capacity. Synthetic-proliferative cells can mature into contractile cells during lung development. ASM cells from asthmatics are hypercontractile, hypersecretory or hyperproliferative. Asthmatic ASM cells express more myosin light chain kinase (MLCK), which may be attributable to the lack of CCAAT-enhancer binding protein (C/EBP) $\alpha$; this may lead to enhanced contractility of cells. Hypersecretion by asthmatic ASM cells may be caused by the altered extracellular matrix (ECM) and by the lack of c/EBP $\alpha$, which would result in enhanced transcription of inflammatory genes including CCL11 and CXCL10. Hyperproliferation of asthmatic ASM cells is thought to be the result of the lack of C/EBP $\alpha$ and the altered ECM in which the cells are embedded. CTGF: connective tissue growth factor.

functions of their own. Integrins (intercellular adhesion molecule-1 and vascular cell adhesion molecule-1) and CD44 are important for the adhesion of T-cells to ASM cells; adhesion between activated T-cells and ASM cells leads to DNA synthesis in the ASM cells [36]. Major histocompatibility complex (MHC) class II and the co-stimulatory molecules CD40 [37, 38], CD80 and CD86 [39] are also present on ASM cells. Despite the expression of MHC class II, ASM cells are not able to present antigen [38]. However, ASM cells and T-cells can activate each other via cell adhesion molecules and costimulatory molecules [39]. It has been reported that ASM cells express OX40 ligand, a member of the tumour necrosis factor (TNF) superfamily expressed on various inflammatory cells including B-cells and dendritic cells, and ligation of this molecule on ASM cells led to IL-6 release [40].

Recently, expression of Toll-like receptors (TLRs; the patternrecognition receptors involved in activation of innate and adaptive immunity) was detected on ASM cells and this expression was shown to be increased upon stimulation with pro-inflammatory stimuli [41]. Activation of TLR2, TLR3 and TLR4 on the ASM cells by their respective ligands led to CXCL8 and CCL11 release, indicating that these TLRs are functional. Furthermore, ASM cells respond to the TLR3 ligand dsRNA (a viral replicative intermediate) by releasing CXCL10, which could lead to the recruitment of mast cells [42]. TLR ligands have also been shown to amplify pro-inflammatory interactions between ASM cells and peripheral blood mononuclear cells by augmenting cytokine and chemokine production by these cells under co-culture conditions [42, 43].
These data show that ASM cells are able to interact with infiltrating immune cells, and may also potentially be involved in innate and adaptive immune mechanisms that underlie airway inflammatory responses.

\section{Asthmatic ASM cells}

Studies using isolated bronchial rings and cultures of isolated ASM cells have shown that asthmatic ASM cells are intrinsically different from nonasthmatic ASM cells: they are hypercontractile, hyperproliferative and hypersecretory (fig. 2) [26, 44-46]. Whether these hypercontractile, hyperproliferative and hypersecretory cells coexist in one person is unknown. It has been shown that proliferative and synthetic ASM populations overlap [47]. However, the idea of phenotype switching implies that contractile and proliferative capacities are opposed to each other. Perhaps multiple phenotypes of ASM cells coexist in the airways and form a heterogeneous population of ASM cells. In patients with asthma, certain triggers may induce proliferation of the synthetic-proliferative ASM cells or induce maturation of cells into contractile cells. For instance, it has been shown that insulin increases the expression of contractile markers and also that certain ECM molecules can alter the phenotype of ASM cells $[48,49]$, suggesting that the environment of ASM cells may influence their function.

Culturing ASM cells from asthmatics is an important tool to study abnormalities in ASM cells; however, since these cells are taken out of their natural environment, culture conditions may alter the phenotype and, since abnormalities may be lost after several passages in culture, caution is needed in interpreting the results derived from these studies. 


\section{ASM REMODELLING: A CAUSE OF ASTHMA?}

In addition to inflammation, remodelling of the airways is also a major histopathological feature of asthma. Remodelling is thought to be the consequence of an aberration of the dynamic process of wound repair that includes matrix production and degradation leading to reconstruction of the tissue. Due to unknown circumstances, this process is disturbed in asthma and leads to enhanced production of matrix, leading to fibrosis of the tissue.

In asthma, airway remodelling is described as increased thickening of the airway wall due to various structural alterations including: abnormal epithelium [50-52], sub-basement membrane thickening [53], alterations in interstitial matrix [54, 55], increased vascularisation [56], alterations in mucous glands or enhanced mucus production [6], and an increase in smooth muscle mass [57]. These alterations are thought to have profound physiological consequences and are thought to be the consequence of the chronic inflammatory response that develops during the disease. The present paper will focus on remodelling of the ASM layer.

\section{Increased ASM mass}

Increased ASM mass was first described in 1878 by STIRLING [58] in lungs from cats that were infected by a nematode worm. He described "inter-alveolar hypertrophy due to a great increase in the number of the nonstriped muscular fibres" (fig. 3). In 1922, Huber and KOESSLER [59] described increased ASM mass in patients with asthma and, in 1969, DunNILL et al. [6] published a paper showing that the amount of ASM in lung tissue was increased in patients who died in status asthmaticus, compared with normal individuals who had died suddenly with no previous history of chronic bronchitis, and with patients who had died with a history of chronic obstructive lung disease without emphysema (chronic bronchitis) or with emphysema. In some studies, the degree of ASM mass increase seems to be related to the severity of asthma [60-62], but even in young asthmatics (aged 17-23 yrs) more ASM mass is detected when compared with age-matched controls [63]. These data, and the fact that in young children airway remodelling is found prior to eosinophilic inflammation and clinical asthma [64, 65], suggest that remodelling, and increased ASM mass in particular, is not the consequence of asthma. This novel view suggests that increased ASM mass is present before symptoms of asthma develop and, therefore, it may be (one of) the cause(s) of asthma.

Studying ASM mass in young children who have not developed clinical asthma could indicate whether increased ASM mass precedes asthma or whether it is a consequence of hyperplasia or hypertrophy caused by the presence of increased growth factors. To completely answer this question it would be necessary to conduct studies performing bronchial biopsies in children; however, due to ethical considerations this would be difficult.

\section{Altered ECM}

In addition to increased ASM mass, alterations in the ECM contribute to the thickening of the airway wall. In asthmatics, the ECM is altered compared with that of healthy subjects, i.e. has increased deposition of collagens I, III and V, fibronectin, tenascin, hyaluronan, versican and laminin [66-68], and decreased collagen IV and elastin deposition [69]. ASM cells isolated from asthmatics have been shown in vitro to produce an altered array of ECM proteins compared with ASM cells from nonasthmatics; they produce more perlecan and collagen I and less laminin- $\alpha 1$ and collagen IV [70]. This may be related to the increased production of connective tissue growth factor (CTGF) observed in asthmatic ASM cells following a profibrotic stimulus [46].

In addition to providing support to tissue, ECM has been shown to modulate cell development, migration and proliferation [71]. The composition of the ECM on which ASM cells grow influences the proliferation rate [72]. ASM cells grown on fibronectin or collagen I proliferated faster in response to mitogens than cells grown on plastic alone, whereas laminin reduced the proliferation rate of ASM cells. ECM produced by asthmatic ASM cells enhanced the proliferation rate of ASM cells (asthmatic or nonasthmatic) grown on it, suggesting that ASM cells, by producing ECM proteins, may modulate their own function. Asthmatic ASM cells can also influence vessel formation in and around the ASM bundle, as CTGF produced by ASM cells anchors vascular endothelial growth factor to the ECM [73].

A recent report by CHAN et al. [26] has shown that the altered secretion of ECM components from asthmatic ASM cells leads to enhanced eotaxin expression, suggesting that the ECM may also influence the synthetic capacity of ASM cells. In addition, ECM proteins are important for phenotype maintenance. Endogenously expressed laminin is required for maturation of ASM cells into a contractile phenotype [48]. ECM was also shown to be involved in regulation of contractility, as culturing of bovine smooth muscle strips on different ECM molecules changed contractile responses. Culturing in the presence of fibronectin and collagen I reduced the contractility of the smooth muscle strips, which was associated with a reduced expression of the contractile proteins sm-myosin and calponin [49].

These data suggest that ECM produced by ASM cells is important in remodelling of the airways, as the ECM profile determines the proliferation, synthetic capacity, phenotype and contractility of ASM cells.

\section{Increased ASM migration}

The presence of an increased smooth muscle layer and "smooth muscle-like cells" or "myofibroblasts" outside the smooth muscle cell compartment has given rise to the novel idea that ASM cells can migrate within the airway wall. Myofibroblasts are thought to originate from fibroblasts [74], fibrocytes recruited from the blood [75] or from epithelial cells that have undergone transition into mesenchymal cells (epithelial-mesenchymal transition) [76]. Another theory is that they are recruited smooth muscle cells that have migrated from the bundles [77]. ASM cells in vitro have the capacity to migrate in response to a growing list of mediators, including growth factors [78, 79], cysteinyl LTs [80], chemokines [81] and cytokines [82]. In addition, the ECM can influence migration of ASM cells. Increased migration of ASM cells was seen when membranes were coated with collagens III and V and fibronectin compared with collagen I, elastin and laminin [78]. Whether migration of ASM cells occurs in vivo remains to be established.

In summary, the existence of airway remodelling before the clinical onset of asthma suggests that remodelling is perhaps 


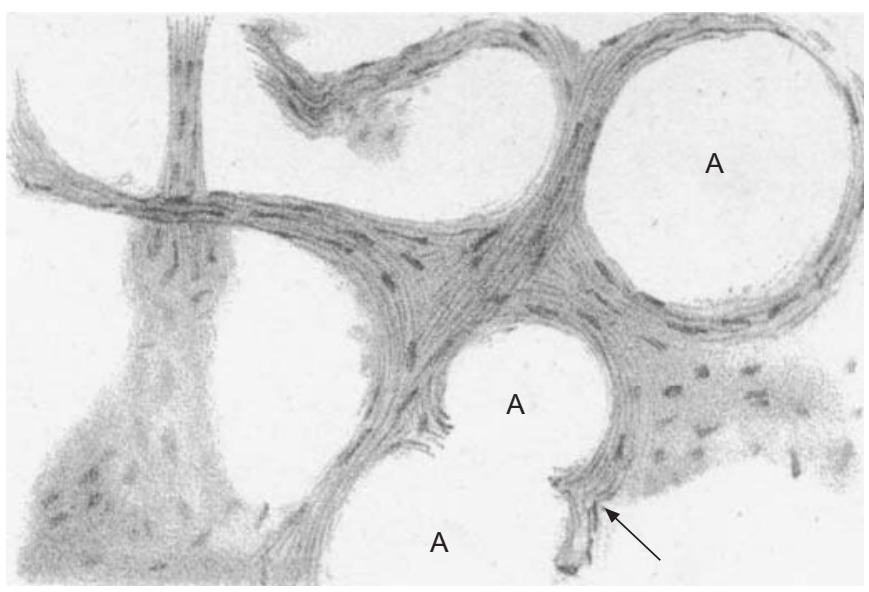

FIGURE 3. Inter-alveolar hypertrophy due to an increase in the number of nonstriped muscular fibres in the lungs of a cat infected by a Nematode worm. The arrow shows the trabecula splitting into muscular fibres. A: air vesicle. Reproduced from [58] with permission from the publisher

(one of) the cause(s) of asthma. Increased ASM mass, altered ECM deposition by ASM cells or migration of ASM cells are correlated to severity of asthma but not duration of asthma, suggesting that the thickening is not the result of asthma but may potentially be the cause.

\section{ASTHMATIC ASM CELLS: IS CCAAT-ENHANCER BINDING PROTEIN $\alpha$ THE PROBLEM?}

Recent studies point to a role for the transcription factor CCAAT-enhancer binding protein $(\mathrm{c} / \mathrm{EBP}) \alpha$ in the altered contractile, proliferative and secretory capacities in ASM cells from asthmatics. Asthmatic ASM cells in culture were shown to lack the anti-proliferative isoform of $\mathrm{c} / \mathrm{EBP} \alpha[83,84]$. This transcription factor may be important in many processes in ASM cells, including the contractility of ASM, as c/EBP $\alpha$ is a possible negative regulator of MLCK expression [84, 85]. Furthermore, it is thought that the lack of the anti-proliferative isoform of $\mathrm{c} / \mathrm{EBP} \alpha$ in ASM cells from asthmatics results in the increase in ASM mass, as this transcription factor regulates proliferation through the regulation of the cell cycle inhibitor p21 waf/cip1 [83]. In addition, steroids also exert their effect via $\mathrm{c} / \mathrm{EBP} \alpha$ through an interaction of the glucocorticoid receptor and $c / E B P \alpha$ that activates $p 21$ [86]. Due to the lack of $c / E B P \alpha$, these drugs are not very potent in inhibiting proliferation of ASM cells from asthmatics.

A recent review by BORGER et al. [85] describes the role of $\mathrm{c} / \mathrm{EBP} \alpha$ in airway inflammation. In short, $\mathrm{c} / \mathrm{EBP} \alpha$ can silence the inflammatory response through interference with nuclear factor (NF)- $\mathrm{kB}$-driven gene expression; a lack of $\mathrm{c} / \mathrm{EBP} \alpha$ will result in more expression of NF-кB-dependent inflammatory genes.

The lack of $\mathrm{c} / \mathrm{EBP} \alpha$ seems a likely candidate to explain the mechanism driving the altered contractility, proliferation and synthetic capacity in asthmatic ASM cells. Whether the lack of $\mathrm{c} / \mathrm{EBP} \alpha$ or other intrinsic differences in asthmatic ASM cells are the cause of asthma remains to be established. Studies focusing on identifying and targeting the differences will lead to a better understanding of the role of the ASM cells in asthma.

\section{ASM CHARACTERISTICS SHOULD BE USED TO PHENOTYPE PATIENTS WITH ASTHMA}

As ASM cells from asthmatic individuals are different from normal and these cells are involved in AHR, remodelling and inflammation, the present authors propose that characterising these cells in patients will lead to better phenotyping and treatment of patients.

Asthma is a complex disease, and asthmatic patients can have different symptoms and respond differently to treatment. Therefore, phenotyping of patients might result in the development of more specific therapies leading to better long-term outcomes. Currently, patients are separated into different classes mainly according to severity of the disease, which is based on the symptoms of the patient, the amount of $\beta_{2}$-agonist reliever medication the patient uses and lung function parameters [87], leading to categorisation into intermittent and three levels of persistent disease (mild, moderate and severe).

WARDLAW et al. [88] suggest that objectively measurable terms should be used to phenotype patients, rather than symptoms that rely on subjective measures. For instance, the pathophysiology could be used, since both the pathology (amount of inflammation, remodelling) and physiology (lung function, AHR, reversible versus fixed airflow obstruction) can be measured. Including immunological findings may also help to develop better treatments for asthma, as a recent study has shown that patients with noneosinophilic asthma benefit less from steroid therapy compared with patients with eosinophilic asthma [89]. If the type of inflammation in the airways of the patient is taken into account, more specific treatments for each phenotype can be developed, which may allow better management of the individual patients.

\section{Phenotyping based on ASM characteristics: ASM mass, intra-ASM inflammation and ASM phenotype}

Considering the novel view of the role of ASM cells in AHR, remodelling and inflammation, these cells should be studied more thoroughly and their phenotype and function taken into account when patients are classified into a specific category. In particular, the amount of ASM mass, mast cell infiltration of the ASM layer and the contractile versus synthetic-proliferative phenotype of ASM cells should be considered when classifying patients, as these features may correlate with severity and AHR.

Increased ASM mass is now being extensively studied by several research groups that are trying to answer the question as to whether patients with different degrees of severity of the disease can be distinguished by specific airway structural components. When patients with intermittent, mild-to-moderate and severe asthma were compared with healthy controls and patients with chronic obstructive pulmonary disease (COPD), the size of the ASM cells and fibroblast accumulation under the basement membrane were increased in severe asthmatics compared with the other patient groups [62]. Furthermore, MLCK content in ASM from severe asthmatics was enhanced and was negatively correlated with pre- and post-bronchodilator FEV1. This study shows that quantification of components of the airway architecture allows the discrimination between severe and milder disease. Another study has shown that an increase in ASM area seemed to be the best marker for severity, as ASM area was 
negatively correlated with FEV1 in severe asthmatics but not in the moderate asthmatics [61], and in severe asthmatics the distance between the ASM and the epithelium is reduced, and more IL-8 and eotaxin is expressed in the ASM. WOODRUFF et al. [60] have found increased ASM volume in patients with mild-tomoderate asthma, which was due to an increase in cell number (hyperplasia) rather than cell size (hypertrophy). EBINA et al. [90] have shown hyperplasia of ASM in subjects with increased ASM mass restricted to central airways, whereas both hyperplasia and hypertrophy were found in patients with increased ASM in central and peripheral airways, suggesting that both hyperplasia and hypertrophy can contribute to increased ASM mass. Together, these studies suggest that increased ASM mass due to hyperplasia or hypertrophy reflects severity of disease and, therefore, the ASM mass could be used as a marker of severity of disease.

However, the studies performed to date have not prospectively addressed whether ASM mass relates to severity of disease. Furthermore, the aforementioned concept of clinical assessment can be challenged as it is not known how specific increased ASM mass is for asthma. HoGg et al. [91] have shown that ASM area is also enhanced in small airways of patients with severe and very severe COPD: Global Initiative for Chronic Obstructive Lung Disease status 3 and $4 ; \mathrm{FEV} 1<50 \%$ predicted with recurrent, life-threatening exacerbations; and impaired quality of life [91]. In this study, thickening of the airway walls, in part explained by increases in ASM mass, had the strongest association with progression of COPD, suggesting that remodelling and increases in ASM mass are not specific for asthma but are a feature of progressive lung disease.

The second ASM feature that can be studied is mast cell infiltration of the ASM layer, since the number of mast cells correlates with AHR; therefore, these cells may influence AHR. Perhaps reducing intra-ASM inflammation will prove more useful than reducing mucosal inflammation. Reducing mast cell recruitment or stabilising mast cells to prevent degranulation are two possible strategies to reduce AHR.

Although there is no direct evidence in vivo for the existence of both contractile and synthetic-proliferative phenotypes of ASM cells, perhaps the phenotype of ASM should still be considered, since it may be a measure of the amount of AHR (contractile) or inflammation and remodelling (syntheticproliferative).

The drawback to using measurements of pathophysiology, immunology and ASM features is that this requires more invasive techniques (sputum, bronchoalveolar lavage, biopsies) than measuring lung physiology alone, and performing all these measurements would be very time consuming. Therefore, finding noninvasive markers of inflammation and remodelling is very important. To date, ASM features have only been studied in bronchial biopsies. If phenotyping based on ASM features is to be used in practice, less- or noninvasive technology should be developed. Using a technique called fibered confocal fluorescence microscopy, the difference in autofluorescence of structures in the bronchial wall is used to

\section{TABLE 1 Airway smooth muscle (ASM) targets for therapy}

\begin{tabular}{|c|c|c|c|}
\hline Target $^{\#}$ & Function & Possible intervention & Status drug \\
\hline \multicolumn{4}{|l|}{ Contractility } \\
\hline MLCK & $\begin{array}{l}\text { Phosphorylates myosin light chain leading to } \\
\text { contraction }\end{array}$ & Reduce activity of MLCK (selective inhibitors) & None \\
\hline RhoA/Rho kinase & $\begin{array}{l}\text { Contraction, gene transcription, migration, } \\
\text { proliferation }[93,94]\end{array}$ & Reduce activation of Rho kinase & $\begin{array}{c}\text { Rho kinase inhibitor: fasudil } \\
\text { Phase II trial in atherosclerosis and } \\
\text { hyperlipidaemia }\end{array}$ \\
\hline \multicolumn{4}{|l|}{ Remodelling } \\
\hline ADAM33 & $\begin{array}{l}\text { Metalloprotease identified as a susceptibility gene } \\
\text { for asthma [95] } \\
\text { Morphogenesis of embryonic lung [96] }\end{array}$ & Reduce expression of ADAM33 & None \\
\hline $\begin{array}{l}\text { C/EBP } \alpha \\
\text { Growth factors (TGF- } \beta \text {, } \\
\text { CTGF, VEGF) }\end{array}$ & $\begin{array}{l}\text { Regulates cell proliferation and inflammation [85] } \\
\text { Increase matrix deposition, } \\
\text { increase angiogenesis }\end{array}$ & $\begin{array}{l}\text { Introduce c/EBP } \alpha \text { into ASM cells } \\
\text { Selective inhibitors }\end{array}$ & $\begin{array}{l}\text { None } \\
\text { Anti-TGF- } \beta \text { phase II in scleroderma } \\
\text { Anti-CTGF phase I in IPF } \\
\text { Bevacizumab phase II in lung cancer }\end{array}$ \\
\hline \multicolumn{4}{|l|}{ Inflammation } \\
\hline MAPK (JNK, ERK, p38) & $\begin{array}{l}\text { Gene transcription, proliferation, } \\
\text { mRNA stability }[97,98]\end{array}$ & Selective inhibitors & $\begin{array}{l}\text { SB-681323 (p38 inhibitor) phase } \\
\text { II in COPD } \\
\text { Phase II in rheumatoid arthritis } \\
\text { Phase II in coronary heart disease }\end{array}$ \\
\hline$N F-\kappa B$ & Gene transcription & Inhibition of NF-кB expression or activity & $\begin{array}{l}\text { IKK-2 inhibitors in vitro and } \\
\text { in an animal model [99] }\end{array}$ \\
\hline CCL11/CCR3 & $\begin{array}{l}\text { Recruitment of eosinophils and mast cells } \\
\text { ASM migration }\end{array}$ & Selective inhibitors & Anti-CCL11 in vitro [100] \\
\hline IL-6 & $\begin{array}{l}\text { Induces secretion of pro-inflammatory and } \\
\text { pro-angiogenic factors [101] }\end{array}$ & Selective inhibitor & Anti-IL-6 phase II in multiple myeloma \\
\hline TNF- $\alpha$ & Increases AHR to methacholine [102] & Selective inhibitor & $\begin{array}{c}\text { Etanercept (TNFR:Fc) } \\
\text { Infliximab (anti-TNF- } \alpha \text { antibody) } \\
\text { Phase II trials in asthma }\end{array}$ \\
\hline
\end{tabular}

MLCK: myosin light chain kinase; c/EBP: CCAAT-enhancer binding protein; TGF: transforming growth factor; CTGF: connective tissue growth factor; VEGF: vascular endothelial growth factor; IPF: idiopathic pulmonary fibrosis; MAPK: mitogen-activated protein kinase; JNK: Jun N-terminal kinase; ERK: extracellular signal-regulated kinase; COPD: chronic obstructive pulmonary disease; NF: nuclear factor; IKK: IKB kinase; IL: interleukin; TNF: tumour necrosis factor; AHR: airway hyperresponsiveness; TNFR:FC: recombinant protein of the human soluble TNF receptor 2 coupled to the Fc portion of human immunoglobulin G. ${ }^{\#}$ : grouped according to proposed mechanism of action; ${ }^{\natural}$ : status of drugs is registered at www. ClinicalTrials.gov. 
detect lung cancer and airway remodelling [92]. Perhaps this technique can also be used to measure ASM mass in asthmatics.

The use of ASM features to phenotype patients may lead to the development of better therapeutic strategies. To direct future therapeutic strategies, specific ASM targets must be identified.

\section{TREATING ASTHMA MEANS TREATING ASM}

Since ASM cells are the most important cells involved in AHR, and have been shown to be involved in remodelling and inflammation, the present authors propose that these cells should be targeted, rather than targeting inflammation or treating symptoms. As described previously, ASM cells cultured from biopsies from asthmatics show different characteristics in different studies. They can either be hypercontractile, hyperproliferative or hypersecretory. Several molecules are thought to be involved in these processes and could be targeted. Table 1 lists some of these molecules and their functions. Possible interventions and known drugs are also identified.

\section{Specific targeting of ASM cells}

A strategy specifically targeting ASM cells should be developed to treat the abnormalities in asthmatic ASM cells. To date, no specific targeting of ASM cells in vivo has been performed. Whether specific targeting is possible and feasible remains to be answered. However, some possible techniques to target these cells are discussed in the current paper.

To specifically target ASM cells, strategies such as local delivery or using an ASM-specific promoter (e.g. the SM22 promoter) could be used. Local delivery with a bronchoscope or administration via an aerosol can specifically target some parts of the airways without systemic involvement and this would reduce unwanted side-effects. The SM22 promoter can perhaps be used to target genes specifically to ASM cells [103, 104]. Post-transcriptional inhibition at the mRNA level can be accomplished using antisense oligonucleotides and small interfering RNAs (siRNAs); these gene-silencing nucleic acids prevent the production of proteins from mRNA. For instance, application of siRNA against NF- $\mathrm{B}$ by transfection of airway epithelial cells reduced TNF- $\alpha$-induced IL- 6 and IL- 8 release [105]. Antisense oligonucleotides can be administered via an aerosol and have been shown to be distributed throughout the lung [106].

In addition to targeting specific components of the ASM cells, another strategy is being explored. Bronchial thermoplasty (BT) is used to obliterate ASM cells from the airway wall. This technique delivers radiofrequency energy to the airway wall, which heats up the airway tissue and reduces ASM mass. Two large clinical studies in mild-to-moderate and severe asthmatics have shown that asthma control and quality of life of these patients was improved by BT, whereas AHR was not affected [107, 108]. This is contrary to a study in 16 mild asthmatics that showed a reduction in AHR that lasted for 2 yrs [109]. The future of this experimental therapy for the treatment of asthma will depend on: 1) the success of this therapy in a placebo-controlled trial in which patients receiving the placebo will also undergo bronchoscopy; and 2) long-term outcomes of lung function, asthma control and quality of life. The long-term effects of this therapy on inflammation and remodelling in the airways of asthmatics that have undergone this treatment have not been examined. It will be important to determine these effects before the longterm benefit of this experimental therapy can be realised.

\section{CONCLUSION}

In conclusion, this perspective outlines the critical role of airway smooth muscle cells in a novel disease paradigm of asthma. These cells: 1) are a part of the inflammatory process in asthma; 2) contribute to airway remodelling; 3) have an altered contractile, proliferative and secretory function in asthmatic airways; 4) can be useful in the phenotyping of patients; and 5) should be targeted to treat asthma. The current authors propose that specific airway smooth muscle targets should be the focus for the development of new interventions in asthma.

\section{ACKNOWLEDGEMENTS}

The authors would like to thank P.S. Hiemstra and K.F. Rabe (both Dept of Pulmonology, Leiden University Medical Center, Leiden, The Netherlands) for helpful discussion and editing of the manuscript.

\section{REFERENCES}

1 Bateman ED, Hurd SS, Barnes PJ, et al. Global strategy for asthma management and prevention: GINA executive summary. Eur Respir J 2008; 31: 143-178.

2 Leckie MJ, ten Brinke A, Khan J, et al. Effects of an interleukin-5 blocking monoclonal antibody on eosinophils, airway hyper-responsiveness, and the late asthmatic response. Lancet 2000; 356: 2144-2148.

3 Djukanovic R, Wilson SJ, Kraft M, et al. Effects of treatment with anti-immunoglobulin $\mathrm{E}$ antibody omalizumab on airway inflammation in allergic asthma. Am J Respir Crit Care Med 2004; 170: 583-593.

4 Milgrom H, Fick RB Jr, Su JQ, et al. Treatment of allergic asthma with monoclonal anti-IgE antibody. rhuMAb-E25 Study Group. N Engl J Med 1999; 341: 1966-1973.

5 Brown RH, Mitzner W, Bulut Y, Wagner EM. Effect of lung inflation in vivo on airways with smooth muscle tone or edema. J Appl Physiol 1997; 82: 491-499.

6 Dunnill MS, Massarella GR, Anderson JA. A comparison of the quantitative anatomy of the bronchi in normal subjects, in status asthmaticus, in chronic bronchitis, and in emphysema. Thorax 1969; 24: 176-179.

7 Jiang H, Rao K, Halayko AJ, Kepron W, Stephens NL. Bronchial smooth muscle mechanics of a canine model of allergic airway hyperresponsiveness. J Appl Physiol 1992; 72: 39-45.

8 Ma X, Cheng Z, Kong H, et al. Changes in biophysical and biochemical properties of single bronchial smooth muscle cells from asthmatic subjects. Am J Physiol Lung Cell Mol Physiol 2002; 283: L1181-L1189.

9 Ammit AJ, Armour CL, Black JL. Smooth-muscle myosin light-chain kinase content is increased in human sensitized airways. Am J Respir Crit Care Med 2000; 161: 257-263.

10 Schaafsma D, Gosens R, Bos IS, Meurs H, Zaagsma J, Nelemans SA. Allergic sensitization enhances the contribution of Rho-kinase to airway smooth muscle contraction. Br J Pharmacol 2004; 143: 477-484. 
11 Lambert RK, Wiggs BR, Kuwano K, Hogg JC, Pare PD. Functional significance of increased airway smooth muscle in asthma and COPD. J Appl Physiol 1993; 74: 2771-2781.

12 Brown RH, Zerhouni EA, Mitzner W. Airway edema potentiates airway reactivity. J Appl Physiol 1995; 79: 1242-1248.

13 Ding DJ, Martin JG, Macklem PT. Effects of lung volume on maximal methacholine-induced bronchoconstriction in normal humans. J Appl Physiol 1987; 62: 1324-1330.

14 An SS, Bai TR, Bates JH, et al. Airway smooth muscle dynamics: a common pathway of airway obstruction in asthma. Eur Respir J 2007; 29: 834-860.

15 Panettieri RA, Murray RK, DePalo LR, Yadvish PA, Kotlikoff MI. A human airway smooth muscle cell line that retains physiological responsiveness. Am J Physiol 1989; 256: C329-C335.

16 Hirst SJ. Airway smooth muscle cell culture: application to studies of airway wall remodelling and phenotype plasticity in asthma. Eur Respir J 1996; 9: 808-820.

17 Halayko AJ, Amrani Y. Mechanisms of inflammationmediated airway smooth muscle plasticity and airways remodeling in asthma. Respir Physiol Neurobiol 2003; 137: 209-222.

18 Halayko AJ, Camoretti-Mercado B, Forsythe SM, et al. Divergent differentiation paths in airway smooth muscle culture: induction of functionally contractile myocytes. Am J Physiol 1999; 276: L197-L206.

19 Ma X, Wang Y, Stephens NL. Serum deprivation induces a unique hypercontractile phenotype of cultured smooth muscle cells. Am J Physiol 1998; 274: C1206-C1214.

20 Halayko AJ, Salari H, Ma X, Stephens NL. Markers of airway smooth muscle cell phenotype. Am J Physiol 1996; 270: L1040-L1051.

21 Owens GK. Regulation of differentiation of vascular smooth muscle cells. Physiol Rev 1995; 75: 487-517.

22 Hirst SJ. Regulation of airway smooth muscle cell immunomodulatory function: role in asthma. Respir Physiol Neurobiol 2003; 137: 309-326.

23 Lazaar AL, Panettieri RA Jr. Airway smooth muscle as an immunomodulatory cell: a new target for pharmacotherapy? Curr Opin Pharmacol 2001; 1: 259-264.

24 Ammit AJ, Bekir SS, Johnson PR, Hughes JM, Armour CL, Black JL. Mast cell numbers are increased in the smooth muscle of human sensitized isolated bronchi. Am J Respir Crit Care Med 1997; 155: 1123-1129.

25 Brightling CE, Bradding P, Symon FA, Holgate ST, Wardlaw AJ, Pavord ID. Mast-cell infiltration of airway smooth muscle in asthma. N Engl J Med 2002; 346: 1699-1705.

26 Chan V, Burgess JK, Ratoff JC, et al. Extracellular matrix regulates enhanced eotaxin expression in asthmatic airway smooth muscle cells. Am J Respir Crit Care Med 2006; 174: 379-385.

27 Brightling CE, Ammit AJ, Kaur D, et al. The CXCL10/ CXCR3 axis mediates human lung mast cell migration to asthmatic airway smooth muscle. Am J Respir Crit Care Med 2005; 171: 1103-1108.

28 El Shazly A, Berger P, Girodet PO, et al. Fraktalkine produced by airway smooth muscle cells contributes to mast cell recruitment in asthma. I Immunol 2006; 176: 1860-1868.

29 Sutcliffe A, Kaur D, Page S, et al. Mast cell migration to Th2 stimulated airway smooth muscle from asthmatics. Thorax 2006; 61: 657-662.

30 Bradding P, Walls AF, Holgate ST. The role of the mast cell in the pathophysiology of asthma. J Allergy Clin Immunol 2006; 117: 1277-1284.

31 Yang W, Kaur D, Okayama Y, et al. Human lung mast cells adhere to human airway smooth muscle, in part, via tumor suppressor in lung cancer-1. J Immunol 2006; 176: 1238-1243.

32 Berger P, Perng DW, Thabrew H, et al. Tryptase and agonists of PAR-2 induce the proliferation of human airway smooth muscle cells. J Appl Physiol 2001; 91: 1372-1379.

33 Brown JK, Jones CA, Tyler CL, Ruoss SJ, Hartmann T, Caughey GH. Tryptase-induced mitogenesis in airway smooth muscle cells. Potency, mechanisms, and interactions with other mast cell mediators. Chest 1995; 107: Suppl. 3, 95S-96S.

34 Chambers LS, Black JL, Poronnik P, Johnson PR. Functional effects of protease-activated receptor-2 stimulation on human airway smooth muscle. Am J Physiol Lung Cell Mol Physiol 2001; 281: L1369-L1378.

35 Johnson PR, Ammit AJ, Carlin SM, Armour CL, Caughey GH, Black JL. Mast cell tryptase potentiates histamine-induced contraction in human sensitized bronchus. Eur Respir J 1997; 10: 38-43.

36 Lazaar AL, Albelda SM, Pilewski JM, Brennan B, Pure E, Panettieri RA Jr. T lymphocytes adhere to airway smooth muscle cells via integrins and CD44 and induce smooth muscle cell DNA synthesis. J Exp Med 1994; 180: 807-816.

37 Lazaar AL, Amrani Y, Hsu J, et al. CD40-mediated signal transduction in human airway smooth muscle. J Immunol 1998; 161: 3120-3127.

38 Lazaar AL, Reitz HE, Panettieri RA Jr, Peters SP, Pure E. Antigen receptor-stimulated peripheral blood and bronchoalveolar lavage-derived $\mathrm{T}$ cells induce MHC class II and ICAM-1 expression on human airway smooth muscle. Am J Respir Cell Mol Biol 1997; 16: 38-45.

39 Hakonarson H, Kim C, Whelan R, Campbell D, Grunstein MM. Bi-directional activation between human airway smooth muscle cells and $\mathrm{T}$ lymphocytes: role in induction of altered airway responsiveness. I Immunol 2001; 166: 293-303.

40 Burgess JK, Carlin S, Pack RA, et al. Detection and characterization of OX40 ligand expression in human airway smooth muscle cells: a possible role in asthma? J Allergy Clin Immunol 2004; 113: 683-689.

41 Sukkar MB, Xie S, Khorasani NM, et al. Toll-like receptor 2, 3, and 4 expression and function in human airway smooth muscle. J Allergy Clin Immunol 2006; 118: 641-648.

42 Morris GE, Parker LC, Ward JR, et al. Cooperative molecular and cellular networks regulate Toll-like receptor-dependent inflammatory responses. FASEB J 2006; 20: 2153-2155.

43 Morris GE, Whyte MK, Martin GF, Jose PJ, Dower SK, Sabroe I. Agonists of toll-like receptors 2 and 4 activate airway smooth muscle via mononuclear leukocytes. Am J Respir Crit Care Med 2005; 171: 814-822. 
44 Johnson PR, Roth M, Tamm M, et al. Airway smooth muscle cell proliferation is increased in asthma. Am J Respir Crit Care Med 2001; 164: 474-477.

45 Johnson PR, Black JL, Carlin S, Ge Q, Underwood PA. The production of extracellular matrix proteins by human passively sensitized airway smooth-muscle cells in culture: the effect of beclomethasone. Am J Respir Crit Care Med 2000; 162: 2145-2151.

46 Burgess JK, Johnson PR, Ge Q, et al. Expression of connective tissue growth factor in asthmatic airway smooth muscle cells. Am J Respir Crit Care Med 2003; 167: 71-77.

47 Sukkar MB, Stanley AJ, Blake AE, et al. "Proliferative" and "synthetic" airway smooth muscle cells are overlapping populations. Immunol Cell Biol 2004; 82: 471-478.

48 Tran T, McNeill KD, Gerthoffer WT, Unruh H, Halayko AJ. Endogenous laminin is required for human airway smooth muscle cell maturation. Respir Res 2006; 7: 117.

49 Dekkers BG, Schaafsma D, Nelemans SA, Zaagsma J, Meurs H. Extracellular matrix proteins differentially regulate airway smooth muscle phenotype and function. Am J Physiol Lung Cell Mol Physiol 2007; 292: L1405-L1413.

50 Laitinen LA, Heino M, Laitinen A, Kava T, Haahtela T. Damage of the airway epithelium and bronchial reactivity in patients with asthma. Am Rev Respir Dis 1985; 131: 599-606.

51 Raeburn D, Webber SE. Proinflammatory potential of the airway epithelium in bronchial asthma. Eur Respir J 1994; 7: 2226-2233.

52 Jeffery PK, Wardlaw AJ, Nelson FC, Collins JV, Kay AB. Bronchial biopsies in asthma. An ultrastructural, quantitative study and correlation with hyperreactivity. Am Rev Respir Dis 1989; 140: 1745-1753.

53 Roche WR, Beasley R, Williams JH, Holgate ST. Subepithelial fibrosis in the bronchi of asthmatics. Lancet 1989; 1: 520-524.

54 Bousquet J, Lacoste JY, Chanez P, Vic P, Godard P, Michel FB. Bronchial elastic fibers in normal subjects and asthmatic patients. Am J Respir Crit Care Med 1996; 153: 1648-1654.

55 Carroll NG, Perry S, Karkhanis A, et al. The airway longitudinal elastic fiber network and mucosal folding in patients with asthma. Am J Respir Crit Care Med 2000; 161: 244-248.

56 Carroll NG, Cooke C, James AL. Bronchial blood vessel dimensions in asthma. Am J Respir Crit Care Med 1997; 155: 689-695.

57 Carroll N, Elliot J, Morton A, James A. The structure of large and small airways in nonfatal and fatal asthma. Am Rev Respir Dis 1993; 147: 405-410.

58 Stirling W. On hyperplasia of the muscular tissue of the lungs. J Physiol 1878; 1: 66-108.5.

59 Huber H, Koessler K. The pathology of bronchial asthma. Arch Intern Med 1922; 30: 689-760.

60 Woodruff PG, Dolganov GM, Ferrando RE, et al. Hyperplasia of smooth muscle in mild to moderate asthma without changes in cell size or gene expression. Am J Respir Crit Care Med 2004; 169: 1001-1006.

61 Pepe C, Foley S, Shannon J, et al. Differences in airway remodeling between subjects with severe and moderate asthma. J Allergy Clin Immunol 2005; 116: 544-549.
62 Benayoun L, Druilhe A, Dombret MC, Aubier M, Pretolani M. Airway structural alterations selectively associated with severe asthma. Am J Respir Crit Care Med 2003; 167: 1360-1368.

63 Bai TR, Cooper J, Koelmeyer T, Pare PD, Weir TD. The effect of age and duration of disease on airway structure in fatal asthma. Am J Respir Crit Care Med 2000; 162: 663-669.

64 Cokugras H, Akcakaya N, Seckin U, Camcioglu Y, Sarimurat N, Aksoy F. Ultrastructural examination of bronchial biopsy specimens from children with moderate asthma. Thorax 2001; 56: 25-29.

65 Pohunek P, Warner JO, Turzikova J, Kudrmann J, Roche WR. Markers of eosinophilic inflammation and tissue re-modelling in children before clinically diagnosed bronchial asthma. Pediatr Allergy Immunol 2005; 16: 43-51.

66 Wilson JW, Li X. The measurement of reticular basement membrane and submucosal collagen in the asthmatic airway. Clin Exp Allergy 1997; 27: 363-371.

67 Roberts CR, Burke AK. Remodelling of the extracellular matrix in asthma: proteoglycan synthesis and degradation. Can Respir J 1998; 5: 48-50.

68 Laitinen A, Altraja A, Kampe M, Linden M, Virtanen I, Laitinen LA. Tenascin is increased in airway basement membrane of asthmatics and decreased by an inhaled steroid. Am J Respir Crit Care Med 1997; 156: 951-958.

69 Bousquet J, Chanez P, Lacoste JY, et al. Asthma: a disease remodeling the airways. Allergy 1992; 47: 3-11.

70 Johnson PR, Burgess JK, Underwood PA, et al. Extracellular matrix proteins modulate asthmatic airway smooth muscle cell proliferation via an autocrine mechanism. J Allergy Clin Immunol 2004; 113: 690-696.

71 Bousquet J, Jeffery PK, Busse WW, Johnson M, Vignola AM. Asthma. From bronchoconstriction to airways inflammation and remodeling. Am J Respir Crit Care Med 2000; 161: 1720-1745.

72 Hirst SJ, Twort CH, Lee TH. Differential effects of extracellular matrix proteins on human airway smooth muscle cell proliferation and phenotype. Am J Respir Cell Mol Biol 2000; 23: 335-344.

73 Burgess JK, Ge Q, Poniris $\mathrm{MH}$, et al. Connective tissue growth factor and vascular endothelial growth factor from airway smooth muscle interact with the extracellular matrix. Am J Physiol Lung Cell Mol Physiol 2006; 290: L153-L161.

74 Powell DW, Mifflin RC, Valentich JD, Crowe SE, Saada JI, West AB. Myofibroblasts. I. Paracrine cells important in health and disease. Am J Physiol 1999; 277: C1-C9.

75 Schmidt M, Sun G, Stacey MA, Mori L, Mattoli S. Identification of circulating fibrocytes as precursors of bronchial myofibroblasts in asthma. J Immunol 2003; 171: 380-389.

76 Willis BC, duBois RM, Borok Z. Epithelial origin of myofibroblasts during fibrosis in the lung. Proc Am Thorac Soc 2006; 3: 377-382.

77 Ronnov-Jessen L, Petersen OW, Koteliansky VE, Bissell MJ. The origin of the myofibroblasts in breast cancer. Recapitulation of tumor environment in culture unravels diversity and implicates converted fibroblasts and recruited smooth muscle cells. J Clin Invest 1995; 95: 859-873. 
78 Parameswaran K, Radford K, Zuo J, Janssen LJ, O'Byrne PM, Cox PG. Extracellular matrix regulates human airway smooth muscle cell migration. Eur Respir J 2004; 24: 545-551.

79 Carlin SM, Roth M, Black JL. Urokinase potentiates PDGF-induced chemotaxis of human airway smooth muscle cells. Am J Physiol Lung Cell Mol Physiol 2003; 284: L1020-L1026.

80 Parameswaran K, Cox G, Radford K, Janssen LJ, Sehmi R, O’Byrne PM. Cysteinyl leukotrienes promote human airway smooth muscle migration. Am J Respir Crit Care Med 2002; 166: 738-742.

81 Kaur D, Saunders R, Berger P, et al. Airway smooth muscle and mast cell-derived CC chemokine ligand 19 mediate airway smooth muscle migration in asthma. Am J Respir Crit Care Med 2006; 174: 1179-1188.

82 Govindaraju V, Michoud MC, Al Chalabi M, Ferraro P, Powell WS, Martin JG. Interleukin-8: novel roles in human airway smooth muscle cell contraction and migration. Am J Physiol Cell Physiol 2006; 291: C957-C965.

83 Roth M, Johnson PR, Borger $\mathrm{P}$, et al. Dysfunctional interaction of $\mathrm{C} / \mathrm{EBP} \alpha$ and the glucocorticoid receptor in asthmatic bronchial smooth-muscle cells. $N$ Engl J Med 2004; 351: 560-574.

84 Shore SA. Airway smooth muscle in asthma-not just more of the same. N Engl J Med 2004; 351: 531-532.

85 Borger P, Tamm M, Black JL, Roth M. Asthma: is it due to an abnormal airway smooth muscle cell? Am J Respir Crit Care Med 2006; 174: 367-372.

86 Roth M, Johnson PR, Rudiger JJ, et al. Interaction between glucocorticoids and $\beta_{2}$ agonists on bronchial airway smooth muscle cells through synchronised cellular signalling. Lancet 2002; 360: 1293-1299.

87 Lemanske RF Jr, Busse WW. 6. Asthma. J Allergy Clin Immunol 2003; 111: Suppl. 2, S502-S519.

88 Wardlaw AJ, Silverman M, Siva R, Pavord ID, Green R. Multi-dimensional phenotyping: towards a new taxonomy for airway disease. Clin Exp Allergy 2005; 35: 1254-1262.

89 Berry M, Morgan A, Shaw DE, et al. Pathological features and inhaled corticosteroid response of eosinophilic and non-eosinophilic asthma. Thorax 2007; 62: 1043-1049.

90 Ebina M, Takahashi T, Chiba T, Motomiya M. Cellular hypertrophy and hyperplasia of airway smooth muscles underlying bronchial asthma. A 3-D morphometric study. Am Rev Respir Dis 1993; 148: 720-726.

91 Hogg JC, Chu F, Utokaparch S, et al. The nature of smallairway obstruction in chronic obstructive pulmonary disease. N Engl J Med 2004; 350: 2645-2653.

92 Thiberville L, Moreno-Swirc S, Vercauteren T, Peltier E, Cave C, Bourg HG. In vivo imaging of the bronchial wall microstructure using fibered confocal fluorescence microscopy. Am J Respir Crit Care Med 2007; 175: 22-31.

93 Gosens R, Schaafsma D, Nelemans SA, Halayko AJ. Rhokinase as a drug target for the treatment of airway hyperresponsiveness in asthma. Mini Rev Med Chem 2006; 6: 339-348.

94 Janssen LJ, Killian K. Airway smooth muscle as a target of asthma therapy: history and new directions. Respir Res 2006; 7: 123.

95 Van Eerdewegh P, Little RD, Dupuis J, et al. Association of the ADAM33 gene with asthma and bronchial hyperresponsiveness. Nature 2002; 418: 426-430.

96 Haitchi HM, Powell RM, Shaw TJ, et al. ADAM33 expression in asthmatic airways and human embryonic lungs. Am J Respir Crit Care Med 2005; 171: 958-965.

97 Gerthoffer WT, Singer CA. MAPK regulation of gene expression in airway smooth muscle. Respir Physiol Neurobiol 2003; 137: 237-250.

98 Ammit AJ. The role of mRNA stability in airway remodelling. Pulm Pharmacol Ther 2005; 18: 405-415.

99 Birrell MA, Hardaker E, Wong S, et al. Iк-B kinase-2 inhibitor blocks inflammation in human airway smooth muscle and a rat model of asthma. Am J Respir Crit Care Med 2005; 172: 962-971.

100 Dent G, Hadjicharalambous C, Yoshikawa T, et al. Contribution of eotaxin-1 to eosinophil chemotactic activity of moderate and severe asthmatic sputum. Am J Respir Crit Care Med 2004; 169: 1110-1117.

101 Ammit AJ, Moir LM, Oliver B, et al. Effect of IL-6 transsignaling on the pro-remodeling phenotype of airway smooth muscle. Am J Physiol Lung Cell Mol Physiol 2007; 292: L199-L206.

102 Thomas PS, Heywood G. Effects of inhaled tumour necrosis factor $\alpha$ in subjects with mild asthma. Thorax 2002; 57: 774-778.

103 Camoretti-Mercado B, Forsythe SM, LeBeau MM, et al. Expression and cytogenetic localization of the human SM22 gene (TAGLN). Genomics 1998; 49: 452-457.

104 Solway J, Seltzer J, Samaha FF, et al. Structure and expression of a smooth muscle cell-specific gene, SM22 $\alpha$. J Biol Chem 1995; 270: 13460-13469.

105 Platz J, Pinkenburg O, Beisswenger C, Puchner A, Damm T, Bals R. Application of small interfering RNA (siRNA) for modulation of airway epithelial gene expression. Oligonucleotides 2005; 15: 132-138.

106 Ali S, Leonard SA, Kukoly CA, et al. Absorption, distribution, metabolism, and excretion of a respirable antisense oligonucleotide for asthma. Am J Respir Crit Care Med 2001; 163: 989-993.

107 Cox G, Thomson NC, Rubin AS, et al. Asthma control during the year after bronchial thermoplasty. $N$ Engl J Med 2007; 356: 1327-1337.

108 Pavord ID, Cox G, Thomson NC, et al. Safety and efficacy of bronchial thermoplasty in symptomatic, severe asthma. Am J Respir Crit Care Med 2007; 176: 1185-1191.

109 Cox G, Miller JD, McWilliams A, Fitzgerald JM, Lam S. Bronchial thermoplasty for asthma. Am J Respir Crit Care Med 2006; 173: 965-969. 